\title{
The Struck-and-Lost Factor in Alaskan Walrus Harvests, 1952-1972
}

\author{
FRANCIS H. FAY, ${ }^{1}$ JOHN J. BURNS, ${ }^{2}$ SAMUEL W. STOKER ${ }^{3}$ and J. SCOTT GRUNDY ${ }^{4}$
}

(Received 16 March 1994; accepted in revised form 11 July 1994)

\begin{abstract}
Struck-and-lost rates during hunts for walruses, Odobenus rosmarus (Linnaeus), in Alaska from 1952 to 1972 did not vary from year to year. On average, $42 \%$ of the animals struck by bullets were lost (i.e., not retrieved). About $55 \%$ of the struck-and-lost animals died immediately; the rest were wounded. Apparently, most of the wounded died soon after they were struck. The sex-age composition of the struck-and-lost animals was about the same as that in the harvest, and the proportion lost did not vary with the size of the group encountered. Claims of reduction in loss rates in recent years, based on improved firepower, are open to question. Considerable improvement in weapons took place also during the 21-year period of this study, but it merely increased the proportion of outright kills among the struck-and-lost animals. It did not reduce the proportion lost of the animals that were struck.
\end{abstract}

Key words: walrus, Odobenus rosmarus, Alaska, harvests, struck-and-lost

RÉSUMÉ. Le taux d'animaux frappés et perdus au cours de la chasse au morse, Odobenus rosmarus (Linnaeus) en Alaska de 1952 à 1972 n'a pas varié d'une année à l'autre. En moyenne, 42 p. cent des animaux frappés par les balles ont été perdus (c.-à-d. non récupérés). Environ 55 p. cent des animaux frappés et perdus sont morts sur le coup et 45 p. cent ont été blessés. Il semble que la plupart de ces derniers soient morts peu de temps après avoir été frappés. La composition selon le sexe et l'âge des animaux frappés et perdus était environ la même que celle des prises, et la proportion des animaux perdus ne variait pas avec la taille du groupe chassé. On peut remettre en question les affirmations des dernières années concernant une réduction du taux de perte causée par l'amélioration de la puissance de feu. Durant les 21 années de l'étude, les armes ont subi de grosses améliorations, mais celles-ci ont tout simplement fait augmenter la proportion des bêtes tuées sur le coup, parmi les animaux qui avaient été frappés et perdus. Les améliorations apportées aux armes n'ont pas réduit la proportion des animaux perdus parmi ceux qui avaient été frappés.

Mots clés: morse, Odobenus rosmarus, Alaska, prises, frappés et perdus

Traduit pour la revue Arctic par Nésida Loyer.

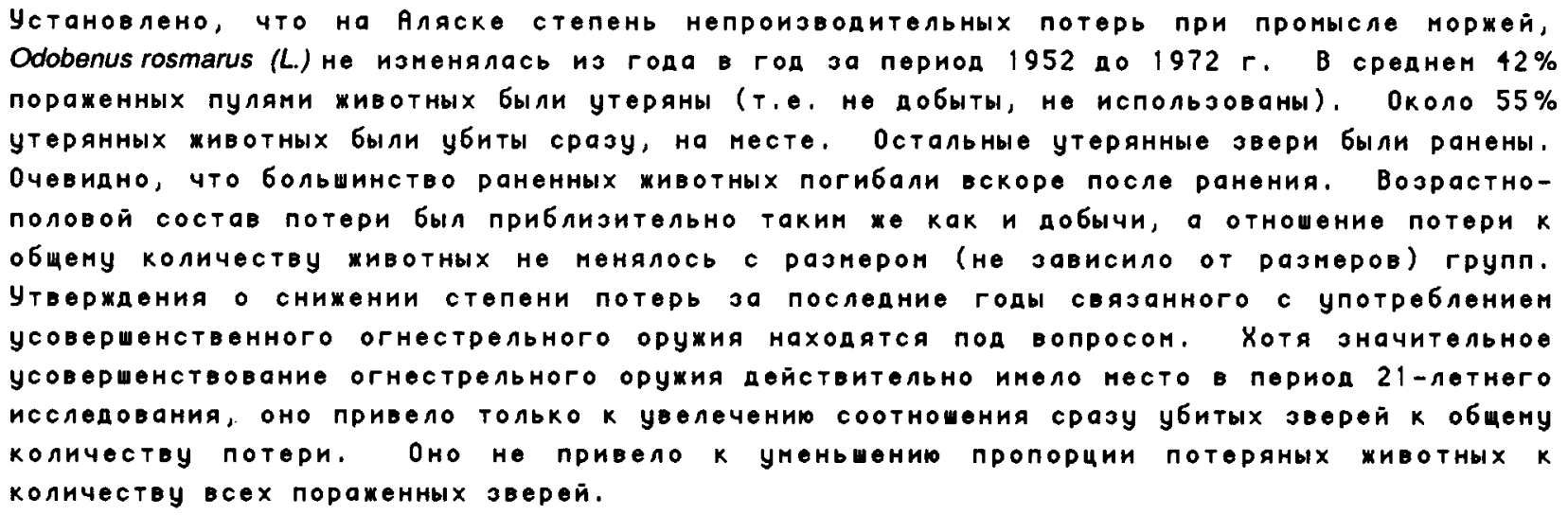

Ключевые слова: морж, Odobenus rosmarus, Аляска, побычн, утерянный

${ }^{1}$ Institute of Marine Science, University of Alaska, Fairbanks, Alaska 99775-7220, U.S.A.

${ }^{2}$ Alaska Department of Fish and Game, Fairbanks, Alaska; Present address: Living Resources Inc., Box 83570, Fairbanks, Alaska 99708, U.S.A.

${ }^{3}$ Institute of Marine Science, University of Alaska, Fairbanks, Alaska; Present address: Beringia Inc., 4920 Anderson Road, Fairbanks, Alaska 99701, U.S.A.

${ }^{4}$ Alaska Department of Fish and Game, Fairbanks, Alaska; Present address: 821 Lancaster Drive, Fairbanks, Alaska 99701, U.S.A.

(c) The Arctic Institute of North America 


\section{INTRODUCTION}

Walruses, Odobenus rosmarus (Linnaeus), have been a renewable resource of great importance to human inhabitants of the Arctic for thousands of years, and they continue to play a major role in the subsistence economy of that region. When walruses were harvested solely by means of harpoons and lances, they probably were taken in small numbers, with little or no loss of dead and injured animals (Clark, 1887; Bockstoce and Botkin, 1982). Upon the introduction of firearms in the nineteenth century, however, those conditions changed markedly. Since then, much larger numbers have been taken, and many of the animals shot have been "lost," i.e., not retrieved (Clark, 1887; Allen, 1895; Petrof, 1900; Arsen'ev, 1927; Bockstoce and Botkin, 1982). This struck-and-lost problem persists today in all areas where walruses are hunted (Kelly, 1990).

The inability to retrieve some of the shot animals is not due to lack of effort by the hunters, for they strive to retrieve them all. The losses are mainly a function of uncontrollable or difficult-tocontrol circumstances associated with the hunt. The primary factor is that a dead walrus in the water "sinks like a stone to the bottom of the sea" (Nechiporenko, 1927:172). For that reason, the hunters usually do not shoot animals in the water, or if they are compelled to do so (e.g., because animals on ice are scarce), they attempt to harpoon them before the fatal shot is fired. If possible, they shoot only walruses that are lying on ice floes, but even those can be lost if the animals are near the edge of the floe when shot, for they often roll into the water and sink. Occasionally, other animals push or pull their dead companions into the water. Walruses are difficult to kill outright; to die instantly, they must be shot in the brain or anterior part of the spinal cord. Animals struck elsewhere are likely to escape, wounded. The hunters are well aware of each of these problems and usually concentrate on overcoming them. Nonetheless, many of the animals that are struck are lost.

For the resource manager, the sinking and wounding of walruses is troublesome, for the magnitude of the annual removal from the population cannot be estimated without considering these losses, which are difficult to measure. The difficulty lies in getting a large set of unbiased observations during harvests that are mostly conducted far at sea by scores of hunters in small boats. Several attempts have been made to estimate the numbers struck and lost in both Alaskan and Russian harvests of Pacific walruses $(O . r$. divergens), but most of those estimates were poorly documented and the proportions were highly variable, ranging from as little as $11 \%$ to more than $60 \%$ of the number shot (Zenkovich, 1938; Brooks, 1953; Harbo, 1959; Kenyon, 1960; Krylov, 1968; Lourie, 1982). Presumably, this wide range was the result of either small numbers of observations or large amounts of bias, or possibly both (Kelly, 1990).

Our objective in this study was to obtain, insofar as possible, a long-term, unbiased data set that would provide a more precise and representative estimate of the struck-andlost rate in Alaskan walrus harvests. We undertook the present analysis of those data primarily to provide an essential component for a back-calculating population model for walruses, as discussed by Testa (1990).

\section{STUDY AREA AND METHODS}

We gathered the struck-and-lost data while monitoring the annual spring harvests of walruses by Native villagers in western Alaska, between 1952 and 1972. To do so, we accompanied as many different groups of hunters as we could on their forays for walruses and other marine mammals. The hunters usually were aware that we were keeping a record of the catch, but we believe that they did not change their tactics in any way because of it. Our data were from animals taken both on the ice and in the water and under a wide variety of ice, weather, and temporal circumstances representative of the normal hunting conditions.

The data were from spring hunts near the major walrus harvesting villages on St. Lawrence, King, and Little Diomede Islands, Alaska (Fig. 1). More than $60 \%$ of the annual Alaskan harvests are taken by those villagers (Sease and Chapman, 1988). Each time the hunters encountered a group of walruses, we recorded the number of animals shot, the number of dead animals retrieved, the number of dead that could not be retrieved, and the number wounded. In most cases, we also recorded the size of the group and, in some cases, the sex and approximate ages of the animals involved.

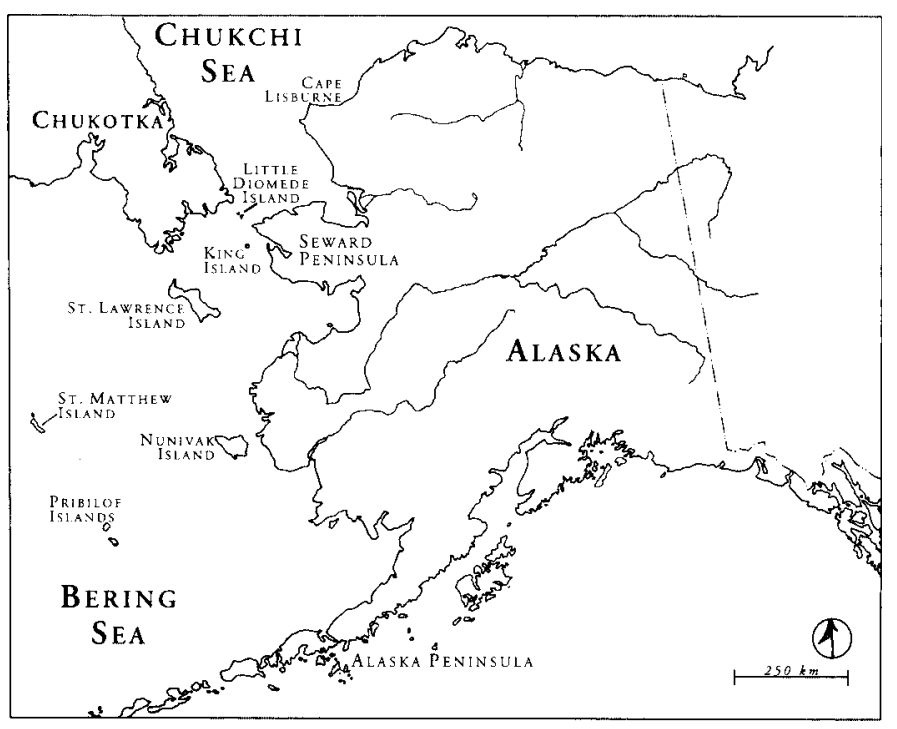

FIG. 1. Map of the Bering-Chukchi region showing the location of geographic points mentioned in the text.

Because the fate of the wounded animals is critical to estimating the rate of removal attributable to the struck-and-lost factor, we attempted to assess the survival rate of the wounded by analyzing data from four other sources. The first was a data set from necropsies of walrus carcasses found along the northern coasts of both the Seward Peninsula and St. Lawrence Island, where they had been carried by ocean currents from the hunting areas. These carcasses were examined during routine surveys from 1975 to 1979 (Fay, 1976; Fay et al., 1977, 1978, 1979a,b). Each carcass was examined for sex, age, and cause of death. Only the intact carcasses with bullet wounds are considered here, since only those could be identified with certainty as having been struck and lost. That is, had they been retrieved at sea, at least the 
head or the tusks would have been removed there. Animals shot in the brain or in the anterior (neck) part of the spinal cord were identified as "killed outright." Those hit in areas other than anterior parts of the central nervous system were identified as having been "wounded." We assumed that there was equal probability that carcasses of wounded animals, as well as those from outright kills, would strand in the same area, if the wounded animals died not long after they were shot. Our objective was to determine whether the proportions of wounded and outright kills in this sample of beach-cast carcasses were the same as or different from the proportions observed during the harvests.

The second source was a series of necropsies of beached carcasses found well away from the principal hunting sites. These carcasses were along the northern coast of the Alaska Peninsula, on St. Matthew Island, and on the southern coast of St. Lawrence Island. Most of them were cases of natural mortality, but among them were a few wounded animals that had survived for weeks, months, or longer after they had been struck and lost. From this set, we expected to obtain a very crude estimate of the proportion of previously wounded animals in the population, based on the ratio of wounded to natural mortalities and the assumption that natural mortality was $>1 \%$ but probably not $>2 \%$ per year (Fay et al., 1979b; DeMaster, 1984).

The third source was a compilation of data from walruses that we and several colleagues examined during Alaskan coastal harvests from 1952 to 1972, and the fourth was a comparable set of animals taken during Russian ship-based harvests from 1976 to 1987. Each harvested animal in those samples was inspected externally and internally for pathological conditions, including bullet wounds, in the course of weighing, measuring, skinning, and dismembering the carcasses for human and animal consumption. We assumed that the proportion of animals previously wounded in these samples would be equal to the proportion of previously wounded individuals in the population as a whole.

\section{RESULTS}

From 1952 to 1972 , we observed at least 500 different encounters between Native hunters and groups of walruses. Shooting took place during more than half of those encounters, and we recorded the results of that shooting on 243 occasions, in which 758 animals were struck by one or more bullets. Of the animals struck, $440(58 \%)$ were retrieved, and $318(42 \%)$ were lost (Table 1). The number retrieved in this sample was about $3 \%$ of the total Alaskan harvests during the 21-year period of observation.

Several of the annual samples were small, but whether taken by year or pooled over years, the proportions struck and lost showed no tendency for either increase or decrease over the 21year period. They did not deviate significantly from the overall mean at any time when pooled sequentially for values of 5 or more per cell $\left(\chi^{2}=12.30, \mathrm{df}=11, p=0.3413\right)$.

In a subsample recorded for sex and relative age, the animals struck and lost had the same sex-age composition as those retrieved. That is, the frequency of occurrence of adult males, adult females, and juveniles of both sexes respectively, in the categories of killed and retrieved $(21,36,11)$, killed and lost
$(4,5,1)$, and wounded and lost $(13,17,2)$ did not differ significantly from each other $\left(\chi^{2}=2.457, \mathrm{df}=4, p=0.652\right)$. The proportion struck and lost in relation to group size also varied little (Table 2). For groups of any size, the proportion struck and lost did not deviate significantly from the mean $\left(\chi^{2}=5.823, \mathrm{df}=8\right.$, $p=0.667$ ).

TABLE 1. Annual summaries of walruses observed to have been struck, retrieved, and lost during Alaskan spring harvests, 1952-1972. ${ }^{1}$

\begin{tabular}{|c|c|c|c|c|c|c|}
\hline \multirow[t]{2}{*}{ Year } & \multirow{2}{*}{$\begin{array}{c}\text { Number } \\
\text { struck }\end{array}$} & \multirow{2}{*}{$\begin{array}{l}\text { Number } \\
\text { retrieved }\end{array}$} & \multicolumn{2}{|c|}{ Numbers Lost } & \multicolumn{2}{|c|}{ Proportions Lost } \\
\hline & & & Killed & Wounded & Killed & Wounded \\
\hline 1952 & 22 & 16 & 1 & 5 & 0.045 & 0.227 \\
\hline 1953 & 28 & 12 & 2 & 14 & 0.071 & 0.500 \\
\hline 1954 & 2 & 2 & 0 & 0 & 0.000 & 0.000 \\
\hline 1956 & 7 & 4 & 0 & 3 & 0.000 & 0.428 \\
\hline 1957 & 3 & 3 & 0 & 0 & 0.000 & 0.000 \\
\hline 1958 & 42 & 23 & 9 & 10 & 0.214 & 0.238 \\
\hline 1959 & 6 & 5 & 1 & 0 & 0.167 & 0.000 \\
\hline 1961 & 8 & 5 & 2 & 1 & 0.250 & 0.125 \\
\hline 1962 & 118 & 72 & 17 & 29 & 0.144 & 0.246 \\
\hline 1963 & 157 & 87 & 43 & 27 & 0.274 & 0.172 \\
\hline 1964 & 15 & 8 & 4 & 3 & 0.267 & 0.200 \\
\hline 1965 & 26 & 18 & 3 & 5 & 0.115 & 0.192 \\
\hline 1966 & 47 & 28 & 15 & 4 & 0.319 & 0.085 \\
\hline 1967 & 122 & 75 & 29 & 18 & 0.238 & 0.148 \\
\hline 1968 & 30 & 13 & 9 & 8 & 0.300 & 0.267 \\
\hline 1969 & 107 & 57 & 36 & 14 & 0.336 & 0.131 \\
\hline 1970 & 1 & 1 & 0 & 0 & 0.000 & 0.000 \\
\hline 1972 & 17 & 11 & 5 & 1 & 0.294 & 0.059 \\
\hline
\end{tabular}

${ }^{1}$ Data of these kinds were not obtained in 1955, 1960, or 1971.

TABLE 2. Numbers of walruses observed to have been struck and lost in relation to group size, during Alaskan spring harvests, 1952-1972.

\begin{tabular}{|c|c|c|c|c|}
\hline \multirow{2}{*}{$\begin{array}{c}\text { Group } \\
\text { Size }\end{array}$} & \multirow{2}{*}{$\begin{array}{l}\text { No. of } \\
\text { Groups }\end{array}$} & \multicolumn{2}{|c|}{ Number of Animals } & \multirow{2}{*}{$\begin{array}{c}\text { Proportion } \\
\text { Lost }\end{array}$} \\
\hline & & Struck & Lost & \\
\hline 1 & 61 & 61 & 22 & 0.36 \\
\hline 2 & 24 & 43 & 16 & 0.37 \\
\hline 3 & 22 & 59 & 27 & 0.46 \\
\hline 4 & 14 & 49 & 16 & 0.33 \\
\hline 5 & 15 & 53 & 26 & 0.49 \\
\hline $6-8$ & 7 & 35 & 12 & 0.34 \\
\hline $9-18$ & 8 & 73 & 26 & 0.36 \\
\hline $19-50$ & 6 & 77 & 30 & 0.39 \\
\hline
\end{tabular}

Of the 318 animals that were struck and lost, $176(55 \%)$ were judged to have been killed outright and lost due to sinking; the rest $(45 \%)$ had been wounded. Of the number struck each year, the proportion wounded showed a trend of continual decline over the 21-year period of observation (Table 1). A complementary trend of increase took place in the proportion of animals killed outright. Both trends were significant (annual samples pooled in chronological order for values $>0: \chi^{2}=33.41, \mathrm{df}=13$, $p=0.0015)$. The greatest contributions to the overall chi-squared value were from samples in the early 1950s (more wounded and fewer killed than expected) and from the late 1960s (fewer wounded and more killed than expected).

In our necropsies of walrus carcasses in the areas downcurrent from principal hunting sites, we found 31 that had been struck and lost. Only 12 (4M, 8F) of these appeared to have been 
killed outright; the other $19(8 \mathrm{M}, 11 \mathrm{~F})$ had been wounded. The ratio of killed to wounded in this sample did not differ from the mean of the harvest samples (Yates' corrected $\chi^{2}=2.51, \mathrm{df}=1$, $p=0.1130$ ). This similarity of proportions and the fact that the carcasses of the wounded animals beached in the same areas as those killed outright suggested that all or most of the animals wounded during the harvest had died soon after they were struck.

Among 64 carcasses examined away from the principal hunting sites, we found that $7(11 \%)$ were gunshot $(5 \mathrm{M}, 1 \mathrm{~F}, 1$ unidentified) and the rest (27M, 28F, 2 unidentified) were cases of natural mortality. Each of the gunshot animals had been wounded and died weeks or months after being struck. Death had been the result of bacterial infection in the wound(s). These findings indicate that a few of the wounded survived for a time, but their numbers in relation to the cases of natural mortality were low. If the latter made up only $1-2 \%$ of the population per year, then the previously wounded animals amounted to not $>0.25 \%$ of the population.

We examined 114 animals from the harvests by Native hunters from 1952 to 1972 and found only two (1.75\%) that had been wounded previously by rifles. Both of those wounds were fresh and still bleeding, having been acquired not more than a day or two before. Our sample from the Soviet ship-based harvests in 1976 to 1987 was much larger $(n=1873)$, but in it we found only four animals $(0.2 \%)$ that had been shot previously. One of those had a wound that was abscessed; the wounds in the others were partly healed. Thus, the findings from both the Alaskan shore-based and the Soviet ship-based harvests confirmed those from the beach-cast carcasses. That is, they indicated that some of the wounded animals did survive for a time, but the proportion in the population was very low, probably not $>0.3 \%$.

\section{DISCUSSION}

The struck-and-lost rates of Pacific walruses have been high since firearms were introduced into the harvesting system more than a century ago. For example, Nye (in Allen, 1880:769) reported that "about 11,000 have been taken and 30-40,000 destroyed" in 1879 by the Yankee whalers. Petrof (1900) and Arsen'ev (1927) claimed that ten walruses were killed for every two or three secured in the late nineteenth century. The only substantive data from that period, however, are the few extracted from whalers' logbooks by Bockstoce and Botkin (1982), and those indicate, conversely, that only about $30 \%$ were lost.

Early in the present century, the proportion struck and lost on the Soviet side of the Bering Sea was reported by Rozanov (1931:49) as "up to 50\%" and by Zenkovich (1938:60) as "not less than $30 \%$ of all of the animals killed." Both of those estimates, however, were based on hunters' opinions, rather than on objectively gathered data. On the American side, Bernard (1925) estimated that about one-third of 1000 walrus carcasses (ostensibly killed by hunters) that drifted ashore north of Cape Lisburne, Alaska in 1923 still had their tusks. This could be interpreted as evidence of a struck-and-lost rate of about $33 \%$, for the tusks would have been removed at sea, had the animals been retrieved there. Thirty years later, Brooks (1953:508) judged that "more walrus are killed and lost than are recovered," and this seemed to be confirmed by Kenyon (1960) and Harbo (1959), who observed that $80(52 \%)$ of 153 animals shot were lost. The hunters whom Kenyon interviewed, however, claimed to have lost only $40 \%$ of the animals.

Reporting on the harvests in Soviet waters in the 1960s, Krylov (1968:190) noted that, "according to our data, 40-50\% [of the animals] from the ship-based harvest sink, and 34\% from the shore-based," but he presented none of those data. He estimated "the average numbers lost at the time of all Soviet harvests to be about 40\%" (p. 190). Elsewhere (p. 189), he stated that the $40 \%$ loss was of "animals that sank and those that went away wounded," and he later confirmed this as being " $40 \%$ of the number of animals shot" (p. 202). In his tabulation of harvests and losses (p. 190), however, he confused the issue by showing estimates of the numbers struck and lost as being equal to $40 \%$ of the number harvested (i.e., as not more than $28 \%$ of the number shot).

More recently, hunters at Nunivak, St. Lawrence, King, and Little Diomede Islands were interviewed by Lourie (1982), to whom they reported that they had lost only $102(11 \%)$ of 950 animals struck in 1982. This was a far lower proportion than any reported before or since, and it has been interpreted by some parties as indicative of a significant improvement in the retrieval rate. Others have interpreted it as possibly a strongly biased sample (Kelly, 1990). The interpretation of improvement was attributed mainly to the higher quality of firearms used in recent years, but in our experience, improved firepower alone simply increases the ability to kill, not necessarily the ability to retrieve. During our 21-year period of observation, we also saw the firepower of the hunters improve markedly, with old weapons such as lever-action 25/35s and 30/30s gradually replaced by newer, higher-powered rifles, such as $.270, .30 / 06, .308$, and .375 calibers. Our data indicate, however, that while the hunters' ability to kill walruses increased steadily during that period, this only increased the proportion of outright kills among the struckand-lost animals; it did not increase the proportion retrieved of the animals that were shot.

We concede that some of our data also could have been biased to some degree, although we tried to avoid that. We are aware, for example, that our ability to keep accurate records could have declined as group size increased, simply because it is difficult to keep track of every shot fired and its effect. There was potential for bias also in some of our judgments of whether struck-and-lost animals were killed outright or merely wounded.

We expected that the struck-and-lost rate for adult males and juveniles of both sexes would be higher than that for adult females, for the males and juveniles are lean in spring and tend to sink quickly, whereas the females tend to be fat, more likely to float, and easier to retrieve (Brooks, 1953, 1954; Fay, 1982). These differences apparently did not affect the retrieval rate, however, for we found no significant correlation with sex or age of the animals shot. We suppose that the lack of a correlation could have been a product of the hunters' differential treatment of the carcasses. That is, being aware of the greater potential for loss of adult males and juveniles, the hunters may have made a greater effort to retrieve them than to retrieve the adult females. 
The data also did not uphold our expectation that the struckand-lost rate would be positively correlated with the size of the group attacked (Burns, 1965). Instead, there was no difference between retrieval from the smallest to the largest groups. It is conceivable, of course, that this aspect of the data also was affected by differential treatment by the hunters or that it was biased by our lesser ability to keep accurate records as group size increased.

For our sample of beached carcasses down-current from the hunting areas, we assumed that the walruses killed outright and those that died soon after being mortally wounded would float ashore in the same areas. That assumption was upheld, for the ratio of killed to wounded in the down-current sample did not differ from the proportion observed in the harvest. This also indicated that all or most of the wounded animals died very soon after they were shot.

The low number of previously wounded animals among the beached carcasses found in areas away from the principal hunting sites also confirmed that there were very few surviving wounded in the population, and this was supported further by our results from inspection of animals taken in both the Alaskan and the Soviet harvests. We acknowledge that our findings in those animals could have been strongly biased, for old, healed bullet wounds are difficult to identify in animals such as walruses, which have many superficial scrapes, punctures, and scars caused by other agents (Brooks, 1954; Fay, 1982). In each case that we examined, however, we relied not only on the presence of abullet toconfirmagunshot wound, butoninternal hemorrhage, broken bones, and other tissue damage. Nonetheless, it is likely that we failed to detect some healed wounds that lacked bullets. It is conceivable also that previously wounded animals might have been under-represented in the harvests, because they were more shy, hence less likely to be taken than those without wounds. Conversely, it is equally conceivable that some of the wounded could have been more vulnerable to capture because they were debilitated by their wounds.

We think that the possible sources for bias in our samples were controlled as well as possible under rather difficult circumstances, and that our results are at least indicative that the annual Alaskan harvests of walruses in the 1950s to early 1970s amounted to only about $60 \%$ of the numbers actually removed from the population by the hunters; the other $40 \%$ was made up of animals that were struck and lost, nearly all of which died soon after they were shot. Some of the hunters maintain that there has been an improvement in the retrieval rate in recent years, but this has not yet been documented. The documentation will be very difficult to accomplish, because current hunting practices involve smaller, faster boats with small crews and no room for observers. Furtherinformation on the survival rate of the wounded also would be useful. Most important, however, is the need to developimproved harvesting methods that can greatly reduce or, preferably, eliminate the struck-and-lost factor.

\section{ACKNOWLEDGEMENTS}

We thank especially the walrus hunters of St. Lawrence, King, and Little Diomede Islands, Alaska for making it possible for us to conduct this study. For their help during the work on Soviet hunting ships, we also thank Yurii A. Bukhtiyarov, Alexei I. Grachev, Susan Hills, Robert R. Nelson, John L. Sease, Alexander G. Somov, and Alexei M. Trukhin. For aid during the beached carcass surveys, we thank Robert A. Dieterich, Brendan P. Kelly, Erik Knudtsen, and Larry M. Shults. We are grateful also to James R. Gilbert, Susan Hills, Brendan P. Kelly, Duncan MacDonald, Randall R. Reeves, Erik A. Rexstad, Robert K. Swihart, J. Ward Testa, Bruce C. Thompson, and five anonymous reviewers for constructive comments on the manuscript. Our project was aided by support from the Zoonotic Disease Program of the Arctic Health Research Center, U.S. Department of Health, Education and Welfare, the Grants-in-Aid program of the Arctic Institute of North America, the University of Alaska's Institute of Marine Science, the Alaska Department of Fish and Game, and the NOAA OuterContinental Shelf Environmental Assessment Program, through interagency agreement with the Minerals Management Service, U.S. Department of the Interior. We also acknowledge valued logistical support received from the U.S. Fish and Wildlife Service, Department of the Interior, and from the All-Union Research Institute of Fisheries and Oceanography, U.S.S.R. Ministry of Fisheries.

\section{REFERENCES}

ALLEN,J.A. 1880. History of North American pinnipeds: Amonograph of the walruses, sea-lions, sea-bears and seals of North America. Miscellaneous Publication No. 12. Washington: United States Geological and Geographical Survey of Territories. 785 p.

1895. A synopsis of the pinnipeds, or seals and walruses, in relation to their commercial history and products. In: Fur seal arbitration, Vol. 1. 53rd Congress, 2nd Session, Senate Executive Document 177. Washington, D.C.: U.S. Government Printing Office. 367-391.

ARSEN'EV, V.K. 1927. The Pacific walrus. Vladivostok: Knizhnoe Delo. 40 p. In Russian.

BERNARD, J.F. 1925. Walrus protection in Alaska. Journal of Mammalogy 6:100-102.

BOCKSTOCE, J.R., and BOTKIN, D.B. 1982. The harvest of Pacific walruses by the pelagic whaling industry, 1848 to 1914 . Arctic and Alpine Research 14:183-188.

BROOKS, J.W. 1953. The Pacific walrus and its importance to the Eskimo economy. Transactions of the North American Wildlife Conference 18:503-510.

- 1954. A contribution to the life history and ecology of the Pacific walrus. M.Sc. thesis, University of Alaska, Fairbanks. 103 p.

BURNS, J.J. 1965. The walrus in Alaska. Its ecology and management. Juneau: Alaska Department of Fish and Game. 48 p.

CLARK, A.H. 1887. The Pacific walrus fishery. In: Goode, G.B., ed. The fisheries and fishery industries of the United States, Section V, Vol. II. Washington: U.S. Government Printing Office. 313-318.

DEMASTER, D.P. 1984. An analysis of a hypothetical population of walruses. NOAA Technical Report NMFS 12:77-80.

ESTES, J.A., and GOL'TSEV, V.N. 1984. Abundance and distribution of the Pacific walrus, Odobenus rosmarus divergens: Results of the first Soviet-American joint aerial survey, autumn 1975. NOAA Technical Report NMFS 12:67-76. 
FAY, F.H. 1976. Morbidity and mortality of marine mammalsBering Sea. In: Environmental assessment of the Alaskan continental shelf. Annual Reports of Principal Investigators for the year ending March 1976, Vol. 1. Boulder, Colorado: United States Department of Commerce. 183-234.

1982. Ecology and biology of the Pacific walrus, Odobenus rosmarus divergens Illiger. North American Fauna No. 74. Washington: U.S. Fish and Wildlife Service. 279 p.

FAY, F.H., and KELLY, B.P. 1980. Mass natural mortality of walruses (Odobenus rosmarus) at St. Lawrence Island, Bering Sea, autumn 1978. Arctic 33:226-245.

FAY, F.H., DIETERICH, R.A., and SHULTS, L.M. 1977. Morbidity and mortality of marine mammals-Bering Sea. In: Environmental assessment of the Alaskan continental shelf. Annual Reports of Principal Investigators for the year ending March 1977, Vol. 1. Boulder, Colorado: United States Department of Commerce. 161-188.

FAY, F.H., DIETERICH, R.A., SHULTS, L.M., and KELLY, B.P. 1978. Morbidity and mortality of marine mammals. In: Environmental assessment of the Alaskan continental shelf. Annual Reports of Principal Investigators for the year ending March 1978, Vol. 1. Boulder, Colorado: United States Department of Commerce. 39-79.

FAY, F.H., DIETERICH, R.A., SHULTS, L.M., MURRAY, N.K., HOOVER, A.A., and KELLY, B.P. 1979a. Morbidity and mortality of marine mammals. In: Environmental assessment of the Alaskan continental shelf. Annual Reports of Principal Investigators for the year ending March 1979, Vol. 1. Boulder, Colorado: United States Department of Commerce. 1-34.

FAY, F.H., SHULTS, L.M., and DIETERICH, R.A. 1979b. Natural mortality of marine mammals in Alaskan waters. In: Melteff, B.R., ed. Alaska fisheries: 200 years and 200 miles of change. Proceedings of the 29th Alaska Science Conference, 1978. Alaska Sea Grant Program, University of Alaska, Fairbanks. 411-412.

HARBO, S.J., Jr. 1959. A study of the walrus and the King Island economy. Juneau, Alaska: Alaska Department of Fish and Game. 47 p.
KELLY, B. 1990. Mortality from catch and natural causes. In: Fay, F.H., Kelly, B.P., and Fay, B.A., eds. The ecology and management of walrus populations: Report of an international workshop. PB91100479. Springfield, Virginia: National Technical Information Service. $49-54$.

KENYON, K.W. 1960. The Pacific walrus. Oryx 5:332-340.

KRYLOV, V.I. 1968. On the present status of stocks of the Pacific walrus and prospects of their rational exploitation. In: Arsen'ev, V.A., and Panin, K.I., eds. Pinnipeds of the northern part of the Pacific Ocean. Moscow: Pischevaya Promyshlennost'. 189-204. In Russian.

LOURIE, K.S. 1982. The Eskimo Walrus Commission 1981-82 walrus data collection program. Nome, Alaska: Eskimo Walrus Commission. 233 p.

NECHIPORENKO, G.P. 1927. The walrus harvest in Chukotka. Ekonomicheskaya Zhizn' Dal'nego Vostoka 5(5-6):169-177. In Russian.

PETROF, I. 1900. Population, resources, and industries of Alaska. In: Compilation of narratives of exploration in Alaska. Washington: U.S. Government Printing Office. 55-281.

ROZANOV, M.P. 1931. The harvest of marine mammals on the Chukchi Peninsula. Sovetskii Sever 1931(6):44-59. In Russian.

SEASE, J.L., and CHAPMAN, D.G. 1988. Pacific walrus, Odobenus rosmarus divergens. In:Lentfer, J.W., ed. Selected marine mammals of Alaska: Species accounts with research and management recommendations. Washington: U.S. Marine MammalCommission. $17-38$

TESTA, J.W. 1990. Population modeling. In: Fay, F.H., Kelly, B.P., and Fay, B.A., eds. The ecology and management of walrus populations: Report of an international workshop. PB91-100479. Springfield, Virginia: National Technical Information Service. 33 38.

ZENKOVICH, B.A. 1938. Development of the harvest of marine mammals in Chukotka. Priroda 1938(11-12):59-63. In Russian. 